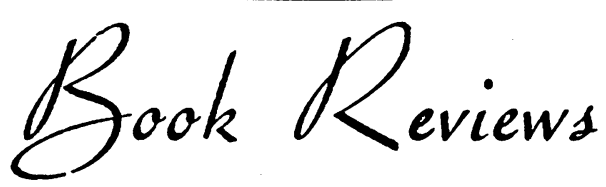

\section{PATHOLOGIE UND KLINIK DES SALZ- UND WASSERHAUSHALTES}

By EdMund Kerpel-Fronius. Verlag der Ungarischen Akademie der Wissenschaften, Budapest. 1959. Pp. 678. Price not given.

This book is written by one of the pioneers in the scientific investigation of disorders of water and salt metabolism in childhood. Even before KerpelFronius went to the United States of America to work with James Gamble, he had made some significant contributions to the study of dehydration, especially by indicating that dehydration is not necessarily isosmolar, but that the tonicity of the extracellular fluid is variable.

This book, however, is not a mere personal record. The literature of the English speaking world is extensively quoted in a text which is written in simple and clear, but inevitably rather ponderous, German. The book is a fine reflection of the high standard of research work which is the tradition of the medical schools in Hungary.

\section{ORTHOPAEDIC SURGERY}

By Sir Walter Mercer. Fifth edition. Pp. xi + $1,040+$ Index and Bibliography. London: Edward Arnold Ltd., 1959. 90s.

The latest edition of this book appears after an interval of nine years, and is slightly increased in size. Several sections have been completely rewritten and the remaining chapters have been revised. The chapters which have been rewritten include one on congenital dislocation of the hip, contributed by G. P. Mitchell. He gives an excellent account of the management of the condition, and discusses the part played by the inverted ' limbus' in preventing complete reduction. The management of excessive anteversion of the femoral neck is also described.

Mitchell has also revised the chapter on poliomyelitis. Active immunization by the use of vaccine is mentioned, and the management of the acute case is described. The treatment of late deformities and paralyses is also considered in some detail.

The section on scoliosis has been revised by Savill. Idiopathic scoliosis is dealt with in detail, and the work of Ponseti and Friedman, and James on the curve pattern in relation to prognosis and treatment is mentioned. Operative correction of severe cases is described briefly.
The chapter on general affections of the skeleton has been extensively revised and several additions have been made to the subject matter, including gargoylism and infantile cortical hyperostosis. Many new illustrations have been added, and this section provides a very useful summary of the subject.

In the chapter on osteomyelitis, the dosage of Penicillin recommended by the author might be considered rather on the low side by many surgeons. Staphylococci do not seem to be as sensitive to Penicillin as they were a decade ago.

The rest of the book contains numerous minor revisions, and a number of new photographs and $\mathrm{X}$-ray reproductions of good quality. The book maintains the high standard of previous editions and provides a very readable account of current orthopaedic thought and practice in this country.

\section{INTERPRETATION OF PAIN IN ORTHOPAEDIC PRACTICE}

By Arthur Steindler, M.D., F.R.C.S. Pp. xvii + 733, illustrated. Springfield, Illinois: Charles C. Thomas. 1959. 148s.

The late Arthur Steindler was a profound thinker and a prolific writer. He always sought to penetrate to the heart of a problem, often bringing an unfamiliar and revealing light to play upon it. He was an inspiring teacher, a devoted doctor and a tireless worker. Many of these qualities are exemplified in this present work, whose final corrections were completed only on his death-bed.

Pain is perhaps the most compelling of all symptoms and this book deals with its orthopaedic aspects. After a general discussion of pain, Steindler discusses its origin in the various tissues of the body; finally he considers the body on a topographical basis, describing how pain may arise in each individual part of the locomotor system, and what treatment is required. Each section is characteristically methodical, thorough and illuminated by case histories. The illustrations are well reproduced and those of anatomical dissections (prepared by Dr. Cosentino) have a clarity usually obtained only in colour photographs.

To some the language and style may not appeal. Although Steindler was a fluent polyglot he lacked the gift of smooth facility in his writings. But this has its advantages, for the reader finds himself pausing at frequent intervals; he is encouraged to 
munch the contents reflectively rather than swallow them whole, which is precisely what the work requires.

Every orthopaedic surgeon should keep this book on his shelf, so that he may browse through small sections in the quiet evenings and dig more deeply when he feels the need to approach a problem from a fresh angle.

\section{TEXTBOOK OF BRITISH SURGERY Vol. 4}

Edited by Sir Henry Souttar and J. C. Goligher. Pp. viii +699 , illustrated. London: William Heinemann Ltd. 1959. I05s.

The fourth and final volume of 'Textbook of British Surgery' deals with inflammation, injuries (including burns) and orthopaedics. For this volume the editors, Sir Henry Souttar and Professor J. C. Goligher have been fortunate to secure the co-operation of Mr. Norman Capener.

The 21 chapters have been written by 17 different authors so that some unevenness is inevitable. Particularly impressive are the sparkling lucidity of Mr. Osmond Clarke's chapter on 'Pain in the neck and arm,' the logical synthesis between pathology and clinical findings in the chapter on 'Inflammation and pyogenic infections,' the thoroughness and clarity of 'Burns' by Mr. John Watson, and the authority and wisdom of the contributions by Mr. Norman Capener, Professor J. I. P. James, Mr. E. N. Wardle and Mr. Leon Gillis. Such selection, however, is invidious and probably highly personal; throughout, the writing is clear, the information up-to-date and somethough not all-of the illustrations are very helpful.

It is evident that complete coverage of orthopaedics has not been attempted, for such subjects as flat foot, hallux valgus and hammer toe are not discussed. For orthopaedic surgeons, it is legitimate to question the proportions of the entire work. This volume is mainly devoted to orthopaedics and is one of four volumes; the proportion seems unduly small for what is by far the largest branch of surgery. In consequence it has been necessary to compress some subjects considerably; for example, fractures and dislocations occupy only 74 pages, apart from an additional 13 pages on mal-union.

There are also internal disproportions within the volume itself: thus, tumours of bone occupy 54 pages while the commoner disorders of the knee joint are disposed of in 14 . Yet, the limitations of space are by no means always a disadvantage, for in many instances they have imposed a conciseness which is admirable.

These detailed criticisms do not detract from the value of the volume as a whole which is a useful and well-produced compendium of modern orthopaedics.

\section{ANTIBIOTIC THERAPY FOR STAPHYLOCOCCAL DISEASES}

Edited by Henry Welch and Maxwell Finland. Pp. 208. Medical Encyclopedia Inc., New York. Distributed by Interscience Publications. \$4.50.

Antibiotic therapy for staphylococcal diseases provides a very full guide to the properties and uses of those antibiotics which are now frequently needed to treat disease due to the more antibiotic resistant strains of staphylococcus.

The introduction summarises the present staphylococcal problem. Dr. Welch points out that the majority of staphylococcal lesions do not require chemotherapy and makes a very salutary comparison between the present-day management of a case of typhoid and that of one of staphylococcal infection, and he ends with a summary of the properties of the more common antibiotics. The following chapters are written by a group of experts, writing one feels with a good personal knowledge of the drugs concerned. Erythromycin, Oleandomycin, Novobiocin, Ristocetin, Kanamycin and Vancomycin, are each discussed in separate chapters. It is perhaps a reflection of the American origin of the book that the chapter on Oleandomycin occupies one quarter of the whole. Although the accent is primarily on the staphylococcal application of these drugs, in describing them comment is also made on their other uses.

The final chapter by Dr. Finland sums up the previous chapters, and gives the book balance with regard to the merits or otherwise of the drugs described and their use in combination.

This book is easy to read and not overburdened with unnecessary detail. Although it contains the relevant theoretical facts it is essentially a practical book and should be well received by clinician and bacteriologist alike.

\section{BIOCHEMISTRY OF BLOOD IN HEALTH AND DISEASE}

By I. Newton Kugelmass, M.D., PhD., Sc.D. Pp. ix +543 , illustrated. Blackwell Scientific Publications, Oxford. 1959. I 26s.

This book has an ambitious object, stated in the preface, " to present the newer knowledge of human blood in health and disease in the light of chemical research, clinical experience and medical necessity'! The author has pursued his task with a catholic taste which has savoured such diverse subjects as vitamins, enzymes and hormones, each of which subjects has a chapter. The whole book abounds with facts and references are extremely copious; one could complain of their number and the uncritical manner in which some are included. As one might expect, the chapters on water and electrolyte metabolism are excellent and the chapter on blood clotting also reflects the author's special experience. Dr. Kugelmass has managed to maintain his interest throughout his wide subject and 